\title{
The Rearticulation of Formal Sediments in Guimarães Rosas's Literary Discourse
}

\author{
A rearticulação dos sedimentos formais no \\ discurso literário de Guimarães Rosa
}

\section{Sérgio Schaefer}

Universidade de Santa Cruz do Sul - UNISC - Rio Grande do Sul - Brasil

\begin{abstract}
This article aims at analysing both the esthetical form and the rearticulation of its internal sediments as proposed by João Guimarães Rosa in his literary works. The analysis' theoretical support is based on Theodor W. Adorno's Teoria Estética. The broad objective of this study is to show that Rosa's esthetical formalization is a call for changing. At the end of the article, a brief comparative study is made between Guimarães Rosa's and Dostoievski's calls for changing. Accordingly, some of the main issues of Bakthin's theories about the works of the Russian writer will be reminded of and some of the main differences and similarities between Rosa's and Dostoievski's formal rearticulations will be pointed out.
\end{abstract}

Key-words: Esthetical form; Formal rearticulation and changing; Guimarães Rosa; Theodor Adorno; Dostoievski.

Resumo: O presente artigo pretende analisar a forma estética e as rearticulações de seus sedimentos internos propostos por João Guimarães Rosa em sua obra literária. O apoio teórico da análise é tomado da Teoria estética, de Theodor W. Adorno. O objetivo geral desse estudo é mostrar que a formalização estética rosiana é um chamamento à mudança. Encerramos nosso estudo fazendo um breve comparativo entre o convite à mudança feito por Guimarães Rosa e Dostoiévski. Para isso, relembraremos alguns dos principais pontos da teorização de Bakhtin a respeito da obra do escritor russo e marcaremos algumas semelhanças e diferenças entre as rearticulações formais rosianas e dostoievskianas.

Palavras-chave: Forma estética; Rearticulação formal e mudança; Guimarães Rosa; Theodor Adorno; Dostoiévski. 


\section{Introduction}

Form is not only the geometrical limits that real objects have. Neither is it the visual perception of the silhouette objects have. It is something else. The form "mother" is something else than just the mother figure. The form "ball" is more than just a sphere: it is play, toy, soccer, competition and so on.

Forms are social and historical sediments. They are saturated with material and cultural contents. Upon observing two houses - a house, a dwelling place, and another house, a dog-house - we perceive in both external spatial and geometrical similarities: both have walls, a roof, a door, a floor. The differences disappear vis-a-vis the similarities. The form resulting from this process of comparison ignores that humans and canines, both living in houses, give different meanings to form, though the form is apparently the same.

If one tree and any other tree can both be externally formalized as trunk, branches, and treetop by giving them, shall we say, a static spatial silhouette, and if we express all this by using the common word "tree", formalization changes when some individual contemplates the trees as likely boards and beams to be used to build a house.

Gérard Genette brings us the example (actually presented by Roland Barthes in his Mythologies) of a photograph that shows a black soldier saluting the French flag. (GENETTE, 1972, p. 187) The author states that the photograph denotes and connotes at the same time, as such is its communicative movement. By denoting, it communicates just this: a black soldier saluting the French flag. By connoting, on the other hand, the photograph communicates (Genette writes "justifies") the political subjection of some African nation to French imperialism. Adorno would state that the photograph says by not saying whatever Gennete places in the field of connotation. Whatever the photograph says by saying - denotation - is presented by means of a form. Whatever it says by not saying - connotation - is presented in some other form.
How possibly may one form turn into another one? How may we capture one form if it does not appear, hic et nunc, clearly expressed in sensorial elements? Form is the articulation of elements that, in a given contextual relationship, promotes one or several meanings. Whenever such elements are rearticulated in other and diverse relationships forms are actually open to doing exactly this - a new form appears. A particular form either is or is not. The not being of a particular form is another being of that form and neither does it annihilate the being that made it meaningful in its prior articulation. The new articulation denies the preceding one without, however, annihilating it.

This way of conceiving form has been proposed by Theodor W. Adorno in his Teoria Estética (2008), in which he analyses several art fields (music, painting, literature, and so on).In this study, we will resort to Adorno's theories as a point of reference to make it clear what esthetical form animates João Guimarães Rosa's literary discourse. We will try to show that Rosas's esthetical formalization is a call for changes. En passant, as this is not the main focus of this paper, we will try to compare Rosa's invitation to changes and that of Dostoievski's in his literary works.

1. Both God and the Devil, in Grande sertão: veredas, are and are not. According to Riobaldo, "everything is and is not". (ROSA, 1972, p. 12) Everything, including the powerful ideas of God and Devil constructed and reconstructed by the human kind along its tortuous history. In a determined articulation of elements, God is form-this, and the Devil is also form-this, while in a new articulation, both become form-that. The pluralizing of the form God in Grande sertão, may be sinthetized esthetically in the following sentence: "Deus existe mesmo quando não há" (God exists (form-this) even when there is not (form-that))". (ROSA, 1972, p. 49) The same may be said as far as the form Devil is concerned: "O Diabo existe (form-this) e não existe (form-that)?" ("Does the Devil exist (form-this) and does it not exist (form-that))?" (ROSA, 1972, p. 11) 
The esthetical form that is and, at the same time, is not, is neither contradictory, nor self-destroying. And neither is it solved in a comprehensive totalizing synthesis. In Guimarães Rosa's artistic-literary context, contradiction has nothing to do with logics, which, according to Breton's surrealism, turns our thoughts into slaves (BRETON, 2007) ${ }^{1}$ and which, according to Rosa himself, does not allow the possibility for us to reach "a higher reality and higher dimensions for magical and new thought systems". (ROSA, 1976, p. 3) ${ }^{2}$ Esthetical forms are contradictory because they say and do not say, they show and do not show, they communicate and do not communicate. By not saying, they do say; by not showing, they do show; by not communicating, they do communicate.

Art forms - either literary, or musical, or pictoric or such others - are ephemeral moments. Forms are contingent, as everything else in our world is. Besides, whatever they refer to as being their truth is also contingent, hence partial, makeshift, factual and just probable. Adorno likes to say that art truths are just will-ó-the-wisps, fireworks, glimmerings in a dark night, which is tantamount to saying that esthetical truth is pluralized and not totalizing. As far as art is concerned, the "whole is the not true". 3 (ADORNO, 1992, p. 46)

We are deceived, deluded as to the partial and contingent aspect of esthetical truths, because of the necessity we have to communicate ephemeral truths by means of a physical support, such as words printed on paper, paint on acanvas, musical notes on the five-line staff. Whenever we feel like it, we may open Guimarães Rosa's Primeiras estórias, and right there, fixed on paper, we will come across the same words, the same stylistic and lexical innovations, the same stories. If we go to the Louvre, in Paris, we

\footnotetext{
${ }^{1}$ Breton, in a passage of Nadja, states that logics is "the most hateful of all prisons". (BRETON, 2007, p. 132)

${ }^{2}$ Guimarães Rosa, in the preface of "Aletria e hermenêutica", in Tutameia, says that literature should "open widely the principles of logics", just as when we tell jokes.

${ }^{3}$ Adorno also insists: any kind of thought or practice (political, economical, technologic-scientific) is not authentic when it becomes systematized, because, when the contingency of reality is silenced, freedom is constrained. According to Adorno, systematizing means subsuming particulars in a whole, in such a way that they lose their identity.
}

may enjoy looking at Leonardo da Vinci's Mona Lisa and her "eternal smile", which is there ever since the canvas was painted (1503-1506). The fixedness of a work of art (which may also disappear, if not well taken care of) is, no doubt, a form. Guimarães Rosa's short story "São Marcos", in Sagarana, once it was given a final period and published in book format, was finally ready - formalized. The publishers of the successive editions of Sagaranatry their best to preserve this form by adding nothing to it and by erasing nothing from it. They just preserve the sameness, as in a ritualistic repetitiveness.

Esthetical forms, actually, are and are not at the same time. If it is true that every esthetical form needs some kind of support to be materialized, it is also true that it transcends this support, which provides it with rigidity and durability. The esthetical form is not only its support; it also transcends it. In "São Marcos" Guimarães Rosa writes: "[...] apart from its pristine meaning, the word was given value by its still untouched edge, that is, for hardly ever having been seen and even less listened to, for hardly ever having been used and, even better, for never having been used." (ROSA, 1978, p. 238)

What Rosa is clearly proposing is that we make some kind of rupture with the catalepsy of commonly used words, which is a feasible way of rearticulating form. Further, in the same short story, Rosa suggests that, before a 'gravatá' (Bromeliakaratas), shaped as an ionic vase, we could say "drimirim" and "amormeuzinho" and, before a giganti ‘angelim' (Parkiapendula/Parkiaplatycephala), we could say "ó colossalidade". What is Rosa explicitly proposing and doing, at the same time? Upon suggesting that we use new words to describe the reality we perceive, in the same formal action we fix them on paper, Rosa is proposing another formalization of language which, in the case of the short story titled "São Marcos", is intentionally and in a professor-like way enunciated. By suggesting that we use new and unusual words, he makes a rupture with the prosaic and usual forms - the ones we use in our daily life - and presents another possible way of expressing reality. In the end, what Rosa is telling 
us (in a very explicit way in "São Marcos") is the following: there are many possible forms for us to express reality. He says it in a fixed form which, apparently, cancels other forms that express reality. This is what is meant by esthetic-formative contradiction. In later works, Rosa does not call our attention so explicitly to form rearticulation; instead, he practices it, as is the case in Corpo de baile, in the epic Grande sertão: veredas, and in several short stories in Primeiras estórias, Tutameia - terceiras estórias, and Estas estórias. ${ }^{4}$

A little further in the same short-story, Rosa removes the limits of some words and gives them new limits in a joking way. The character is walking down the woods and advances 'péporpé' (foot by foot): "Péporpé, péporsi... Péporpé, péporsi... Pepp or pepp, epp or see... Pépeorpépe, heppeOrcy..." (ROSA, 1973, p. 252)

Are we before the Joyce who wrote Finnegans Wake? Actually, even if only here and there (as Rosa is not the language anarchist that Joyce was) the writer from Minas Gerais does propose another new form of language, different from the one we have so far analysed, although maintaining some degree of kinship with it, quite often, reality cannot be expressed either by usual words, already consecrated by common usage, or by invented words that are different in their similarity, like "colossalidade" or "amormeuzinho" (which remind us of "colosso", "colossal" and "meu amorzinho").

We have just finished pointing out three types of formalization in the short story "São Marcos": first, the form fixed by a physical support; second, the lexical innovation; third, the difficulty we have to express reality, arising from the limits of language. We may say, if we so desire, that form needs some kind of signifier in order to signify, which becomes quite clear in "São Marcos", according to what we have so far seen. Firstly, the ample signifier, that is, the complete short story itself, the story narrated in such or such way, intent on saying something.

\footnotetext{
4 One exception: the four prefaces interplaced in Tutameia terceiras estórias are intended as an orientation, as well as an explication, on how literary and linguistic forms may be broken and how Rosa himself tries to do it.
}

Secondly, the signifiers of the new words, rearticulated from usual signifiers and intent on saying something else. Thirdly, the signifiers of strange words, non-existing in the field of the already formalized spoken or written language, and which, on their turn, also intend to communicate something. Three fully signifying propositions, three forms.

2. Rosa's literary works are made up of a complex tangle of esthetically proposed forms. One such form, the one dealing with lexical innovation, does not twinkle with the same intensity from work to work, from short story to short story, from story to story. Such twinkling may be more dazzling in some cases, not so intense in others, and even more pedestrian in still other cases; it may even shine visibly in some remote corner of the sky or of the human psyche. More often than not, such innovations get mixed up with the rescue of archaic language, with regional language, with indigenous words, and brazilianisms (proporema, brujajara, panema, seresma) or else with tactics of re-arrangement or cosmetic interventions in well-known words (aumentante, inteligentudo, inaudimento, orabolas, remorto, porcoespim).

Still another form, namely, syntactic rearticulation, according to Paulo Rónai, is one of the most daring achievents in Rosa's art:

However, Rosa's style is most daring, even sharp and hermetic, as far as syntax is concerned: Guimarães Rosa's phrases are loaded with meanings that abound in nonexpressed meanings, which play with anacoluthons, with reticence, and omissions of popular inspiration [...] (RÓNAI, 1991, p. 532$533)^{5}$

In "Reminisção", a short story in Tutameia, the following sentence is re-syntacticised: "Que quis falar, quis, pôde é que foi não.” (Rosa, 1976, p. 83) In common language the sentence would be expressed like this: "Quis falar e não pôde." (He wanted to speak but he could not). This is a

\footnotetext{
5 Paulo Rónai, in his essay, analyses the short stories in Tutameia - terceiras estórias and the above quotation refers to the syntax of these short stories. Rónai's statement, however, may be extended to other writings by Rosa.
} 
standard-example of syntactic reordination. It makes writing, speaking, and communication awkward. It makes them different, but does not eliminate understading. But Rosa is not interested only in rearticulating this or that sentence. And neither is it in his syntactically reorganized phrasal unit that Rosa's most daring art may be perceived, just as it is not in the heads of women or of horses freely floating in Guernica that Picasso's daring cubistic art may be perceived. It is, rather, in the reordination of Rosa's discourse, in how phrases are reordinated among themselves, that strangeness and difference are produced, so much so that communication tends to be hermetic. Notwithstanding, the discourse in "Reminisção" does communicate, does say something, namely, that it is possible to transvert aspects of reality, "to also appreciate the seamy side of reality" (ROSA, 1976, p. 81) and see beauty in whatever is ugly. We may see the inside-out features of reality. Concerning this story, Paulo Rónai says, "whatever is not begins to influence effectively whatever is, to shape it, to change its features" (RÓNAI, 1991, p. 533) Drá, the female character, is not beautiful - "é feia feito fritura queimada" (she is as ugly as burnt fried food), "é de partir o espelho" (she makes a mirror crack) - but Romão, her husband, sees her as a beautiful woman. Whatever is not, is. Or else, whatever is is likely not to be.

Despite the syntactic difficulties the discourse presents, the differences of which cause strangeness, the story may be understood. Actually, "Reminisção" has several re-worked forms: words, phrases, the general form of the story (its narrative movement) and, for sure, the form that most particularly calls our attention, the ugly-beautiful form.

It is by lexical and syntactic rearticulation that Rosa succeeds in practicing what Adorno understands as being one of the most important aspects of modern and contemporary art, namely, the enigma. Rosa's works do not propose mysteries; they do propose enigmas. Mysteries are empty, enigmas may be solved.Both God and the Devil, in Grande sertão: veredas, are enigmatic formalizations. Riobaldo, by means of a gradual and conflicting process of deciphering, tries to make the dense fog that hides such cultural forms vanish ${ }^{6}$. The artistic treatment given by Rosa to the God-Devil enigma is most outstanding in Grande sertão, although we would not say it is the most important one. There is a major enigma that goes beyond Grande sertão and all its particular enigmas, and which characterizes Rosa's works, namely, the enigma of change, which can be thus summarized, as previously stated: "everything is and is not". If everything is the way it is, in the next moment it is not as it used to be, although it keeps being what it is. Therefore, everything is and, at the same time, is not.

3. What can an artist-writer do to propose in a literary way the enigma of change, that is, just as far as esthetics go, without doctrinal, ideological or instrumental biases ${ }^{7}$ By using the tools available to him in this art field, that is, language and words, by integrating words in phrases, by ordering and reordering them. The artist-writer has a store of ready linguistic forms (signifiers and signified) available to him, all of them loaded with social and historical sediments. Change will take place by rearticulating internally such forms, by revolving its sediments, by rearticulating them and thus redirecting its possibilities. According to Adorno, this is exactly what Schönberg accomplished when he used the material available to him, the twelve notes of the musical scale, to compose serial-dodecaphonic music. (ADORNO, 2007) ${ }^{8}$

The esthetical form that lies open to the enigma of change does not say in an explicit way, is not a direct message. It does not say how changes will take place, what direction they will take. This

\footnotetext{
6 Guimarães Rosa makes an effort to send the reader the following message: deciphering God and the Devil is, ultimately, deciphering man, the human, man's tendencies to do good and evil.

7 Doctrines, ideologies, and rational intrumentalities are ancillary to some kind of system. A thought system, like the one by Hegel, ends up subsuming changes in the immobility of the Absolute.

${ }^{8}$ Adorno severely criticizes Schönberg's dodecaphonic system because he instrumentalized rationally the new musical consonance (Stimmigkeit) he himself proposed. Adorno, in his Filosofia da nova música, writes the following: "The total rationality of music consists in its total organization" (ADORNO, 2007 , p. 60 ), that is, its totalitarian organization.
} 
particular form of art has no answers. Just enigmas. Changes may or may not take place. In this form of art nothing is necessary. As Adorno says, "The necessity of art is its non necessity". (ADORNO, 2008, p. 378)

When Guimarães Rosa changes the esthetical-literary form in its syntactic and lexical dimensions, he says by not saying that it is necessary to change. He says neither what, nor how, nor when, nor where. And neither does he say that changes must be triggered. The proposition comes prepared as an enigma to be solved, if such be the case. When Picasso adopts the cubist pictorial form the geometrization of figures in severed bidimensional planes - he proposes another possibility of depicting reality. Such way of showing things says something by not saying it. That's what happens in Guernica (1937) or in The Crying Woman series (1937). Both present the enigma of violence: is a world without violence possible? As we do not know the answer, a non-violent world belongs in the field of enigma.

That is why art, and whatever constitutes art, the esthetic form, is founded on negativity. The mimesis of a work of art takes place by negation. It is an imitation of whatever is not. What is proposed in a work of art - as in Guimarães Rosa and in Picasso is what is missing in them: practical changes in our concrete world. Both artists dream about different worlds. Upon creating in such and such way their esthetic forms, they negate the world form we live and die in.

Luiz Costa Lima says that the negativity that appears in art, from the nineteenth century on, is mimesis or imitation of the kind of society that art is produced in, rather than negation of that particular society. Capitalism is a negating economic, political and social movement, and this negating character is transmitted to art. But, according to Costa Lima, this is not enough for art, thus mimetized, to negate negation, that is, that it proposes something different. Accordingly, Costa Lima rescues the difference which, for him, is inherent to the semantic nucleus of the form mimesis. This is the other side of the similar
/ different logical binary. To insist that art is just negativity would privilege one of the terms of the binary that makes up the semantics of mimesis, that is, similarity. So that art may function in late capitalistic society, that is, so that art may start a process of 'disartisation'9 and (may) have its safe place and function in society, art must be mimesis in the sense of "bringing about the difference". (COSTA LIMA, 2003)

Bringing about the difference, on the other hand, is also a negating act, as it negates similarity. According to Costa Lima, such negation explains the negativity inherent to the capitalistic system. By bringing about the difference, art would therefore be proposing an affirmative world which, on its turn, should again be negated, so that the term difference might continue having the logical importance required by this kind of mimesis. Costa Lima does not go that far, but this has to be presupposed as a non-said implicit.

The difference-producing mimesis, in Adorno's theories, becomes the enigma that is extended as far as the undetermined field of utopia. Adorno's esthetical enigma also has to do with negating the similarity. It is proposed as the possible construction of the difference. ${ }^{10}$ That is why a work of art such as Rosa's, by means of lexical and syntactical innovations, and by the rearticulation of formal elements, produces the difference, but this difference has to do with the enigmatic, with the utopic, which is not taken into account by Costa Lima. That is to say, the difference presented requires that we do some deciphering that is not conducive to certainties, only

\footnotetext{
9 Disartisation: Entkunstung. The word is Adorno's and fits here. It means, mainly, the subsumption of art in the market circuit, which turns it into a negotiable valuable, hence in an object of consumerism inside a movement formalized in such a way that particularities lose their identities.

10 Costa Lima, in Mimesis e modernidade (2003, p. 95-96) rejects negativity as a producer of the differences discussed by Adorno in his Teoria Estética. He understands that Adorno makes of negativity an immanent form of the artistic (of the poetic), that is, he sees negativity as the very character of each and every work of art, thus making it atemporal and fixed. We do not agree with Costa Lima's reading. Adorno insists that art advances because it rearticulates the esthetic form to bring about the difference and that this phenomenon takes place as it accompanies the progress of the productive forces and of the production relations. Besides, Costa Lima's interpretation clashes with the understanding of negativity as discussed by Adorno in Dialética negativa.
} 
to probabilities. The enigma of change, which in Guimarães Rosa arises from the rearticulation of multiple lexical forms and from rearranging them syntactically in a renewed way, is marked by the difference. In Rosa's art, the different is different because it brings about changes in literary-esthetic form. The enigma, therefore, remains, and is restricted not only to the artistic field of literature but to all fields related to man. By Rosa's literature we are summoned to change. It is an invitation to change and changes may begin to take place whenever and wherever we so desire, in any kind of human dimension, without giving us assurance, however, that whatever changes we would like to take place will actually happen. Nothing is guaranteed by the esthetical form in its utopian appeal.

The uncertainty provoked by the multiple possibilities of solving the enigma arises from the form informed by the difference. The difference belongs in the form, and so does the uncertainty. How do such contents - difference and uncertainty happen in Rosa's works? Lexical innovation and syntactical reordering or rearranging are a key-factor for this to happen. When Rosa writes that the wind "igreja as árvores" (churches the trees):"o vento úa, morrentemente, avuve, é uma oada - ele igreja as árvores" (ROSA, 1979, p. 142) ${ }^{11}$, he is rearticulating both the meaning of the noun church and of the verb to church. Neither the noun church, igreja, nor the verb to church, igrejar, has anything to do with the common meaning of church, or, for that matter, with the possibility of making the noun church a verb. There happens a redetermination of meaning which, besides provoking the artistic surprise of the reinformed or transformed form, brings about three esthetical facts: the difference, the change, and the uncertainty as to the fixity of the commonly available meanings. Starting from this kind of experiments, the literary language and its capacity of communication increase the level of uncertainty. We are no longer sure that words mean what they commonly mean.

\footnotetext{
11 Most of the texts written by Guimarães Rosa are very difficult to be translated into other languages. As a rule, the translation of his works, some more some less, betray meanings and, hence, impair semantic equivalence.
}

Such uncertainties appear through Rosa's works from beginning to end.

Depending on the re-worked form, the esthetics triggered by Guimarães Rosa leads us to consider as uncertain - even very uncertain imaginary figures that, in our culture, we take for granted. Such is the case of God and the Devil in Grande Sertão: veredas. Rosa tries to make the reader see that both God and the Devil are and are not; they exist and they do not exist. Even though Rosa's contradiction is not logic but literary only (esthetic, artistic), hence developed in diversified periods of time and under different aspects, it intends to shake our belief in God and in the Devil, that is, as they are proposed in metaphysically anthropomorphized personifications. Rosa himself solves the contradiction, by de-anthropomorphizing these two imaginary figures while, at the same time, anthropologizing them: human beings, while moving in this world, while making up their history, while traveling across their passage in this world, may be divine or diabolical, may do good or evil deeds.

Most of the facts narrated in Grande sertão: veredas have to do with the rearticulation of the GodDevil form. Not all, though, and not always. "Veredas" (narrow waterways) may be discovered by accident by the "jagunços" while they wander along the "sertão": "Vereda em vereda, como os buritis ensinam, a gente varava para após." (ROSA, 1972, p. 46) In such cases, the form "vereda" is rearticulated in the narrational movement as a point of passage, a transition from one place to another one, and, quite often, as space-time for rest and physical recovery from the hardship of the "sertão" life. This, shall we say, is a microunderstanding of the form "vereda". But Grande sertão demands that microforms be integrated in macroforms. In this way, "vereda" is rearticulated to mean Riobaldo's crossing. As this crossing has to do with the major forms God and Devil, good and evil, "vereda" may, in some moments of the plot, be direct part of the major forms. That is what happens in "Veredas Mortas" (Dead waterways) (ou "Tortas") (or Crooked). Riobaldo says, "Estradas vão para Veredas Tortas - 
Veredas Mortas". (ROSA, 1977, p. 76) (Roads go to Crooked waterways- Dead waterways.) He adds, "Lugar não onde", that is, uncertain place. However, a little further on, the Veredas Mortas are precisely located by Riobaldo. (ROSA, 1972, p. 303-304; 316320) Right there the form "vereda" is rearticulated to signify a pact either with the Devil, or with evil, or with oneself, with the human tendencies to do evil. The Devil is, even when he is not, that is to say, the possibility of doing evil exists, even when good prevails.

The "Liso do Sussuarão" (The Sussuarão Plains) is a place-form in the geography of Grande sertão, but, as soon as it is rearticulated, it is included in the God-Devil / Good-Evil macroform. The first crossing of the "Liso", under Medeiro Vaz, is unsuccessful. The second one, under Riobaldo, is successful. (ROSA, 1972, p. 39, and following; p. 382, and following) In these two model-examples "vereda, liso" - we may perceive that Guimarães Rosa reaticulates several individual forms, directing them to becoming a general form. This, however, is accomplished in such a way that the individual forms do not lose their inherent consonance (Stimmigkeit): the "veredas" preserve their individual identity, including the "Veredas Mortas", as does the "Liso do Sussuarão". That is why the transition from one form to another is not a logical transition, subsuming particulars in the universal known as concept. The esthetic literary form is not interested in concepts. It does not reduce "veredas" to the "vereda" concept, and neither does it reduce "liso" to the "liso" concept. The literary object says many words by using one word, reconstructs many meanings by using just one meaning. Form is informed with multiple pieces of information. Literary multiplicity precludes the uniformity of universalized concepts. It is democracy par excellence. It is anti-authoritarianism.

That is why the esthetic rationality is presented in essay-like form. The form essay pursues the contingencies of reality. It does not aim at subjugating the object. In order to avoid doing it, it allows the object to speak. The object, on its turn, says different things in different moments. The artist- subject will endeavour to coordinate such differences, without subordinating them to a systematic form; upon doing it, his individual mark is left on the object which, however, does not become disfigured. The form essay coordinates the elements, rather than subordinating them". (ADORNO, 2003, p. 43)Thus, as every object is free to manifest itself, every subject who constructs a work of art is likewise free to capture such manifestations and, on its turn, manifest itself. In literary art, the object that speaks is, first of all, a subject that speaks to another subject. Both have something to say. The result of such interaction is esthetic form. Besides coordinating the differences of the object, the artist needs to make an effort to coordinate his own differences, so that all this richness may not be reduced to some kind of uniformity. Uniformity kills the differences that give life to forms.

Guimarães Rosa writes the following: "O mato - vozinha mansa - aeiouava" (ROSA, 1979, p. 134). (The wood - soft voice - aeiouava). The whisperings, the murmurs, the little noises of the form wood are listened to by the artist according to the verbalized sequence of the vowels. Here we have a rearticulation of the general form vowel, apparently fixed, tautologic $-a$ is $a, e$ is $e$, and so on. The paradigm of the Portuguese language teaches us that the five vowels of the Portuguese language are just vowels and nothing else. Guimarães Rosa "unparadigmizes" such dogmatic teaching. Upon putting the five vowels together in a verbalized group, Rosa already produces the first unusual difference. Upon relating such verbalization to the form wood and its noises, perhaps captured in a breezy moment, a second difference is produced, now in the form wood, as the wood does not communicate itself by means of a word ordered by vowels. It might be said that Rosa is anthropomorphizing the form wood. In this case, anthropomorphism is a likely resource (a technique) to beautify the esthetics of form. Beauty and ugliness are human constructs. Nothing is, in itself, either beautiful or ugly.

At the beginning of "Buriti", it is said that "o sertão é de noite" ("the sertão is nights"). A little 
further on, it is said that in the opinion of a character called ChefeZequiel, "a noite é um estudo terrível" (night is a terrible study). (ROSA, 1979, p. 8 and p. 91) Zequiel is a half-wit character whom night terrorizes, and that is why the perceptions he has at night become terrifying. His terrified features belong in the form ChefeZequiel, but Guimarães Rosa seizes this form to present the numberless meanings that night may have, if we are artistically willing "to study it", that is, to let it speak. The novel-like short story "Buriti" is a demonstration of this essayistic effort. Its general form, the narrative development, is a caleidoscopic essay made up of linked-together essays: essays about the forms lô Liodoro, Maria Behu, Dona Lalinha, Maria da Glória; essays about the night, the day; essays about Buriti Grande, o Brejão do Umbigo and such others.

The essay form, in literature, is close to the impressionistic form in painting. Monet tries to capture the light variations that take place on the facade of Rouen cathedral in various moments during the day and in different climate situations. He paints fifty variations of the same facade, not a single one like the other. Sameness is always appearance. Essays try to capture the momentary, which makes the same appear as another same. The facade of the Rouen cathedral keeps standing there. But Monet does not intend to paint the facade; what he does intend is to paint the changes that take place on the facade. This is the true object of his painting, this is his esthetic truth. This truth, actually, is a lot of interrelated truths.

The Minas Gerais "sertão" is also right there. Guimarães Rosa is not willing to write about the "sertão", but rather about the changes that take place in the "sertão". His theme, his subject matter, if we may say so, is change or changing, which are the true objects of Grande sertão: veredas. As the semantics of the form change is made up of difference and similarities (the "sertão" both is and is not), the esthetical truths that shine in Grande sertão are legitimized by the similarities in the object "sertão", a form available to the artist-writer, and by the differences that take place in this form. Changes are not only the different: they are the different in the similar. They are the other hues and the other shades of luminosity on the facade of the Rouen cathedral, whether under a noon-sun or under a just-risen sun. If the facade is seen with the eyes of similarity, it seems to remain always the same. Art, particularly contemporary and modern art, endeavours to capture the difference, which is a basic trait of an identity that becomes form by rearticulation. The identity of something is preserved by the non-identity of the moments, which are, on their turn, internal identities of the form, constituted in the difference. The "sertão" in Rosa seems to be the same; it is always, however, a different "sertão". Everything is and is not.

4. Even though the artist may be conscious of the mutability of forms, he may let himself be bewitched rather by similarities than by differences. Such bewitching is one of the most powerful tendencies of our rationality. But does this natural tendency have good effects on human kind? Doubtless, as is proved by the scientific knowledge and all its practical effects on so many technological achievements. We need not reject sciences, and neither should we, and their conceptual uniformizations, which would be naïve. When Magritte, in his Golconda (1953), makes Belgian public workers fall from the skies like rain, attired in black and wearing bowler hats, as if they were water drops, he is not theorizing about gravity forces. Guimarães Rosa presents both the "sertão" natural landscapes and the "sertão" human landscape, as well as its political, cultural and economic aspects, with careful fidelity and seriousness. His "sertão", however, is not approached by a scientific bias. Guimarães Rosa's artistic praxis is oriented towards whatever is changeable, rather than interested in bundling up whatever is changeable in manifold ways in fixed forms, which are devoid of life because, in them, particularities disappear in the mists of the universal.

However, there is in Guimarães Rosa, and Óscar Lopes called our attention to this point (LOPES, 1969), a tendency to stabilize the mutability of form, in order to give it its proper face. Lopes 
perceives it when he analyses the short-story "Soroco" in Primeiras estórias. Stabilization takes place when Rosa turns some form into a noun by making a definite article, mainly used in the singular form, precede it. In "Soroco" Rosa writes, "Sempre chegava mais povo - o movimento" (More and more people kept arriving - the movement). "O trem apitou, e passou, se foi, o de sempre" (The train whistled, and went by, was gone, the usual"). "Soroco se esquisitou, parecia que ia perder o de si, parar de ser" (Soroco felt strange. It seemed he was about to lose himself, to cease being). "Foi o de não sair mais da memória" (It was the not leaving the memory anymore). (ROSA, 1968 , p. 15, 17, 18)

According to Óscar Lopez, the first modelexample freezes the movement of the arrival of more people. The movement of people, always multiple, difficult to be captured, and giving way to a constant enrichment of form, undergoes a "cristalização súbita" (a sudden crystalization), in Lopez's critical assessment. The second example removes the coming and going of the train "from time and space", which is what happens when the diversity of reality is punctuated in the uniformity and universality of a concept. It is then concluded that the train movement is always the same. The third model-example also tends to paralyse Sorocos' inner self, his way of being himself. The paralysis, however, is contradicted by the verb "parecer" (to seem), a fact not perceived by Lopez. In this way, form, whose internal movement is momentarily suspended, may or may not lose the rigidity of the concept. In this case, to seem is a call for keeping being by being, that is to say, Soroco's being did not actually cease being, it just seemed to cease. The fourth model-example, still according to Óscar Lopez, nominalizes the event that moves the story, turns it into a noun: the song, the singing, which, once individual, becomes collective. Here, turning the event into a noun or substantive, means to make it substantial, that is, to make it into something that does not change but, at the same time, remains as a substract for changes. This is the reason why the Portuguese literary critic retranslates the phrase "Foi o de não sair mais da memória" into the form "Deu-se o inesquecível" (The unforgettable happened), "o inesquecível" (the unforgettable) being the name of this substantiality. (LOPEZ, 1969, p. 362)

Such model-examples of form immobility, which appear here and there, are part of Soroco's, his mother's, his daughter's general form, of the "time structure of the narrative", as Lopez writes. The narrative time is doubly presented by Rosa: "imperfect" past tense and, towards the end of the narrative, simple past tense. "Imperfect" past tense: "as muitas pessoas já estavam" (the many people would already be), "sempre chegava mais gente" (more and more people would always be arriving), "a hora era de muito sol" (the sun would then be shining intensely), "aí, paravam" (then they would stop); simple past tense: "Soroco não esperou" (Soroco did not wait), "ele se sacudiu" (he shook himself), "virou pra ir-s'embora" (he turned, to go away), "mas, parou" (but he stopped), "a gente se esfriou, se afundou" (we became cold, we sank). Lopez states that this literary technique is conducive to "anular 0 tempo" (annulling time) (LOPEZ, 1969, p. 345), or rather, it tries to paralyse time, and that such would be a platonizing religious experience characteristic of Rosa's (as it is of Fernando Pessoa's, too). As is well-known, Plato annuls contingency in perfect, immutable, and necessary Forms or Ideas, made eternal in the topos noetos.

But Óscar Lopez did not perceive that the story ends in the "imperfect" past tense, rather than in the perfect past tense: "A gente estava levando agora Soroco para a casa dele, de verdade. A gente, com ele, ia até onde que ia aquela cantiga" (we would then be taking Soroco home, his actual home. With him we would go as far as that song would go).(ROSA, 1968, p. 18; our emphasis)

If Guimarães Rosa is once tempted by the rational power that paralyses movement, he immediately denies what he had denied before. If Rosa's works, as a whole, are beautiful because of their mobile formalization, the overcoming of the moments when form seems to be subjected to hypnotic sleep makes them even more beautiful. 
5. The various moments in Guimarães Rosa's literary discourse are works of art. According to Adorno, a work of art endeavours to rearticulate - sometimes in more creative and daring ways, sometimes in less the linguistic material as well as the possibilities of communication presented to him as sediments to make up the esthetic form. Something like that was also brought about in Dostoievski's literary works, and Bakhtin was able to perceive with great insight the innovations present in the works of this Russian writer:

In our opinion, Dostoievski is one of the major innovators in the field of artistic form. We are convinced that he has created an entirely new kind of artistic thought, the one we usually call polyphonic. [...] We may even say that Dostoievski has created a kind of new artistic model of the world, in which many of the basic moments of the old artistic form have undergone radical transformation. (BAKHTIN, 2010, Introduction, p.1)

Between Guimarães Rosa and Dostoievski there are, undoubtedly, similarities. But there also exist differences. The main similarity is the esthetic proposition formalized as a call for change. The old 19th--century Russia - Dostoievski's lived from 1821 to 1881 - politically structured by the centralized czar regime, is esthetically contested in Dostoievski's works by what Bakhtin calls polyphony, dialogism, and carnivalization. The word is always ready to be dissolved and re-signified by several characters, both in novels and in short stories, but mainly in the major novels of the Russian writer. It is art proposing change in its particular fashion, not only in esthetic form proper, but by indirect ways, as Bakhtin well perceived, by proposing a "new artistic model of the world", that is, a new form of structuring society, democratic, open to dialogue and to differences.

Guimarães Rosa's call for change through his several rearticulations of the esthetic form, like in Dostoievski, also goes beyond the artistic-literary field. Rosa's art is an invitation to changing the political, economical, and cultural "sertão world", that is, of those Brazilian areas that remain stationary in aged social relations, basically cemented by the domination of the weaker by the stronger and, as a consequence, by submitting the first to the latter.
If this similarity brings the two writers closer, it is, on the other hand, marked formally by emphatic differences in Rosa's works. Guimarães Rosa yearns for a different world - or for a different "sertão", since the "sertão" is the world - without destroying whatever constructive aspect the world (sertão) may have, particularly its way of speaking, its way of expressing itself through typical customs, its courage to live and survive, the simple things of its daily life, its all but umbilical, admiring, and tender link with the earth, its vegetation, its animals, its geographic features. The Minas Gerais writer works and reworks the articulations of the "sertão" formal sediments with extreme competence and creative freedom. Dostoievski does also propose the subversion of the established order, but without reworking the lexical and grammatical sediments of the Russian language. His formal strategies envisage the re-structuring of the plot, of the conflict of ideas, of the dialogicpolyphonic way of triggering such conflicts, of the carnivalized deconstruction of socially assimilated concepts, as well as of the contestation of institutionalized ways of human inter-relations

No doubt both Guimarães Rosa and Dostoievski untie conceptual knots firmly embedded in the Brazilian and Russian linguistic tradition. But Rosa's dialogic polyphony between characters is less anguishing and his carnivalization is closer to daily life, almost telluric - except in Grande sertão: veredas, a masterpiece in which the battle between good and evil, or between God and the Devil, assumes epic and tragic characteristics at the same time.

The differentiation inside the unit places Guimarães Rosa and Dostoievski among the writers who were best able to articulate the formal sediments of words and of their conceptual contents, petrified by time. Their formal rearticulations do not beautify just books, they also open space for the enigma of rebeautifying the social structures. If we resist assuming the task of rebeautifying the world, it is predominantly because we allow sameness to enslave us in routine and massification. 


\section{Bibliographical References}

ADORNO, Theodor W. Teoria estética. Translation by Artur Morão. Lisboa: Edições 70, 2008.

O ensaio como forma. In: Notas de literatura I. Translation and presentation by Jorge de Almeida. São Paulo: Duas Cidades/ Editora 34, 2008.

Filosofia da nova música. Translation by Magda França. São Paulo: Perspectiva, 2007.

Minima moralia. Translation by Eduardo Bicca. São Paulo: Ática, 1992

BAKHTIN, Mikhail. Problemas da poética de Dostoiévski. Translation by Paulo Bezerra. Rio de Janeiro: Forense Universitária, 2010. Fifth edition.

BRETON, André. Nadja. Translation by Ivo Barroso. São Paulo: Cosac Naify, 2007.

COSTA LIMA, Luiz. Mímesis e modernidade formas das sombras. São Paulo: Paz e Terra (Graal), 2003. Updated second edition.

GENETTE, Gérard. O reverso dos signos. In: Figuras. Translation by Ivonne Floripes Mantoanelli. São Paulo: Perspectiva, 1972.
GUIMARÃES ROSA, João. Grande sertão: veredas. Rio de Janeiro: José Olympio, 1972. Eighth edition.

São Marcos. In: Sagarana. Rio de Janeiro: José Olympio, 1973. Sixteenth edition.

Soroco, sua mãe, sua filha. In: Primeiras estórias. Rio de Janeiro: José Olympio, 1968. Fourth edition.

Buriti. In: Noites do sertão. Rio de Janeiro: José Olympio, 1979. Sixth edition.

Reminisção. In: Tutameia - Terceiras estórias. Rio de Janeiro: José Olympio, 1976. Fourth edition.

LOPES, Óscar. Guimarães Rosa. In: Ler e depois. Literary critic and interpretation/1. Porto: Editorial Inova, 1969.

RÓNAI, Paulo. Tutameia. In: Guimarães Rosa. Collection organized by Eduardo F. Coutinho. Rio de Janeiro: Civilização Brasileira, 1991. Second edition. (Col. Fortuna Crítica 6).

\section{COMO CITAR ESSE ARTIGO}

SCHAEFER, Sérgio. A rearticulação dos sedimentos formais no discurso literário de Guimarães Rosa. Signo, Santa Cruz do Sul, v. 42, n. 74, maio 2017. ISSN 1982-2014. Disponível em: <https://online.unisc.br/seer/index.php/signo/article/view/8982>. Acesso em: http://dx.doi.org/10.17058/signo.v42i74.8982. 